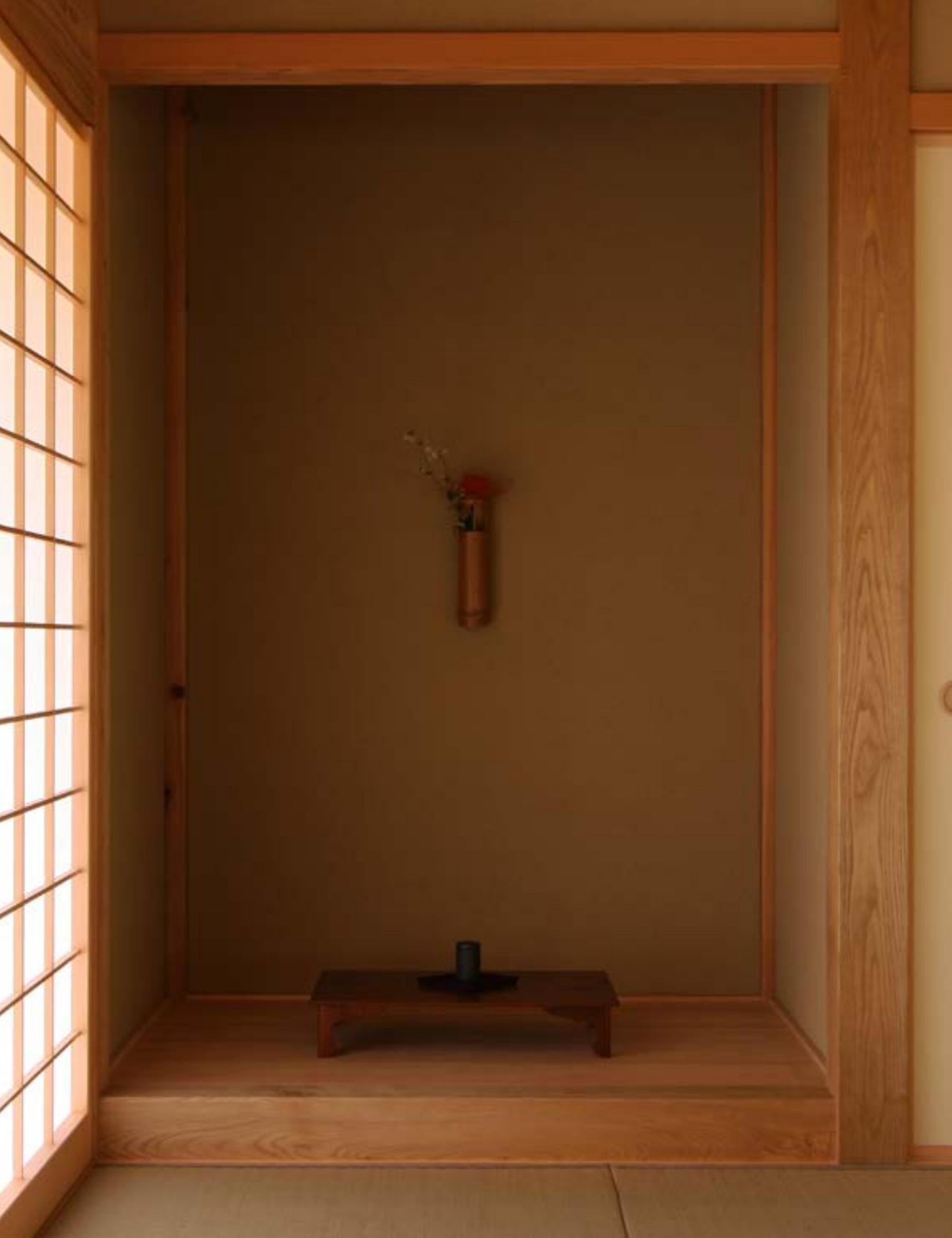




\title{
A Traditional Japanese House with a Jointed Wooden Frame and Tsuchikabe Walls: the Kamogawa House in Chiba
}

\author{
Una casa japonesa tradicional con armazón \\ de madera ensamblada y muros tsuchikabe: \\ la Casa Kamogawa en Chiba
}

\section{Uma casa tradicional japonesa com uma armação de madeira articulada e paredes tsuchikabe: a Casa Kamogawa em Chiba}

This house in Kamogawa, in the prefecture of Chiba, is a single-story wooden dwelling with a total floor area of $59.5 \mathrm{~m}^{2}$. It was begun in April 2010 and completed in October 2011. As the clients were a couple with two young children, we designed the house with a view to creating a family home.
$<$ Tokonoma (alcove) in the Kamogawa House | Tokonoma (nicho) en la Casa Kamogawa | Tokonoma (alcova) da Casa Kamogawa

$>$ Exterior of the Kamogawa House Exterior de la Casa Kamogawa | Exterior da Casa Kamogawa (Masao Nishikawa, Jutaku-Kenchiku, 2011)
Esta casa en Kamogawa, en la prefectura de Chiba, es una vivienda de madera de una planta con una superficie total de $59,5 \mathrm{~m}^{2}$. Se comenzó en abril de 2010 y se terminó en octubre de 2011. Como los clientes eran una pareja con dos niños pequeños, diseñamos la casa con la intención de crear un hogar familiar.

\section{Makoto Fukada}


techniques from my mentor, I extended my knowledge of building techniques by working on demolitions of old Japanese folk houses, exploring other sources of knowledge and carefully studying the structures and forms I encountered.

I love Japanese traditional architecture and have a profound respect for traditional building methods, which represent the wisdom of our forebears crystallized in a tangible heritage. I work to keep that legacy alive through a la tradición. Yo soy uno de ellos. Tras aprender los rudimentos con mi mentor, amplié mis conocimientos sobre técnicas constructivas trabajando en la demolición de antiguas viviendas populares japonesas, explorando otras fuentes de conocimiento y estudiando atentamente las estructuras y formas que encontraba.

Me gusta la arquitectura tradicional japonesa y siento un profundo respeto por los métodos de construcción tradicionales, que representan la sabiduría de nuestros antepasados cristalizada en un sou um deles. Após ter aprendido técnicas básicas com o meu mentor, expandi os meus conhecimentos sobre técnicas de construção, trabalhando em demolições de antigas casas populares Japonesas, explorando outras fontes de conhecimento e estudando cuidadosamente as estruturas e formas que encontrei.

Adoro a arquitectura tradicional Japonesa e tenho um profundo respeito pelos métodos tradicionais de construção, que representam a sabedoria dos nossos predecessores, cristalizada num património

Erection of the framework of the Kamogawa House | Construcción del entramado de la Casa Kamogawa | Montagem da armação da Casa Kamogawa (Ken Kusakari)

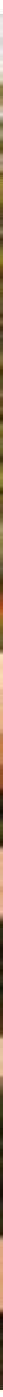


my building company, Seyseysha, which has completed seven original homes and restored three existing structures using traditional woodbuilding methods in both interiors and construction.

Traditional Japanese building techniques involve a framework combining traditional shikuchi (angle joints) and tsugite (straight joints where timbers are placed end to end for greater length) with tsuchikabe (wattle and daub walls of mud plaster mixed with straw), ishibadate (pillars standing freely on stones rather than driven into the ground), and other components to patrimonio tangible. Trabajo para mantener vivo este legado con mi empresa de construcción, Seyseysha, con la que hemos realizado siete viviendas originales y restaurado tres estructuras existentes utilizando métodos de construcción en madera tradicionales tanto en interiores como en la obra.

Las técnicas de construcción japonesas tradicionales se basan en un armazón que combina las típicas shikuchi (juntas de ángulo) y tsugite (juntas rectas donde las maderas se colocan extremo con extremo para tener mayor longitud) con tsuchikabe (tabiques encestados o encañizados revestidos con barro), ishiba- tangível. Eu trabalho para manter esse legado vivo através da minha empresa de construção, Seyseysha, que concluiu sete casas originais e restaurou três estruturas existentes utilizando métodos tradicionais de construção em madeira, tanto em interiores como na construção.

As técnicas de construção tradicional Japonesa baseiam-se numa estrutura que combina as shikuchi (juntas angulares) e tsugite (juntas rectas onde as madeiras são colocadas umas no seguimentos das outras para se obter uma maior envergadura) tradicionais com as tsuchikabe (paredes de taipa com argamassa de barro misturado com palha), ishibadate (pila-

1: Prepared beams and sashigamois for the Kamogawa House 2: Assembling a kanawatsugi joint at the Kamogawa House 3: Log beam and pillar forming an aigaki-watariago/jyuhozo joint in the Kamogawa House | 1: Vigas y sashigamois preparados para la Casa Kamogawa 2: Ensamblaje de una kanawatsugi en la Casa Kamogawa 3: Viga de rollizo y poste de rollizo formando una junta aigaki-watariago/jyuhozo en la Casa Kamogawa | 1: Vigas e sashigamois preparados para a Casa Kamogawa 2: Montagem de uma junta kanawatsugi na Casa Kamogawa 3: Viga de tronco e pilar formando uma junta aigaki-watariago/jyuhozo na Casa Kamogawa (1-3: Ken Kusakari)
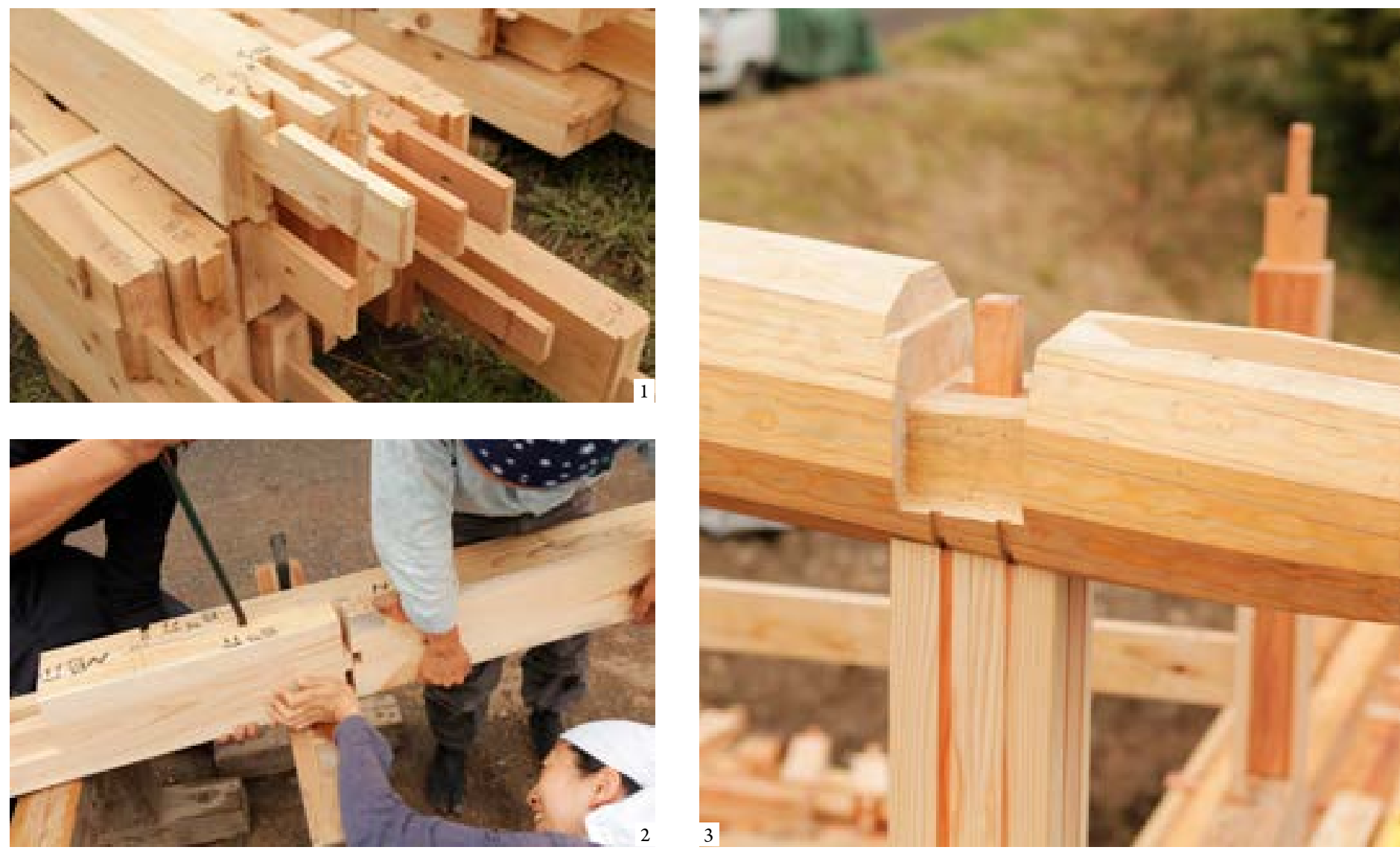
create a structure that harnesses the qualities of wood for optimal structural integrity. We used the same formal approach for the Kamogawa House, with a structural design - and also a floor plan and aesthetic - embracing methods that date back centuries.
Erection of the framework of the Kamogawa House | Construcción del entramado de la Casa Kamogawa | Montagem da armação da Casa Kamogawa (Ken Kusakari) date (pilares apoyados sobre piedras en lugar de anclados en el terreno) y otros elementos para crear una estructura que aprovecha las cualidades de la madera para conseguir una integridad estructural óptima. Utilizamos el mismo planteamiento formal para la Casa Kamogawa, con un diseño estructural -así como una planta y una estética- para el que adoptamos métodos centenarios. res que se posicionam livremente sobre pedras em vez de serem introduzidos no chão), e outros componentes para criar uma estrutura que aproveite as qualidades da madeira para uma integridade estrutural óptima. Utilizámos a mesma abordagem formal na Casa Kamogawa, com um desenho estrutural - e também uma planta e estética - que inclui métodos que remontam a séculos atrás.
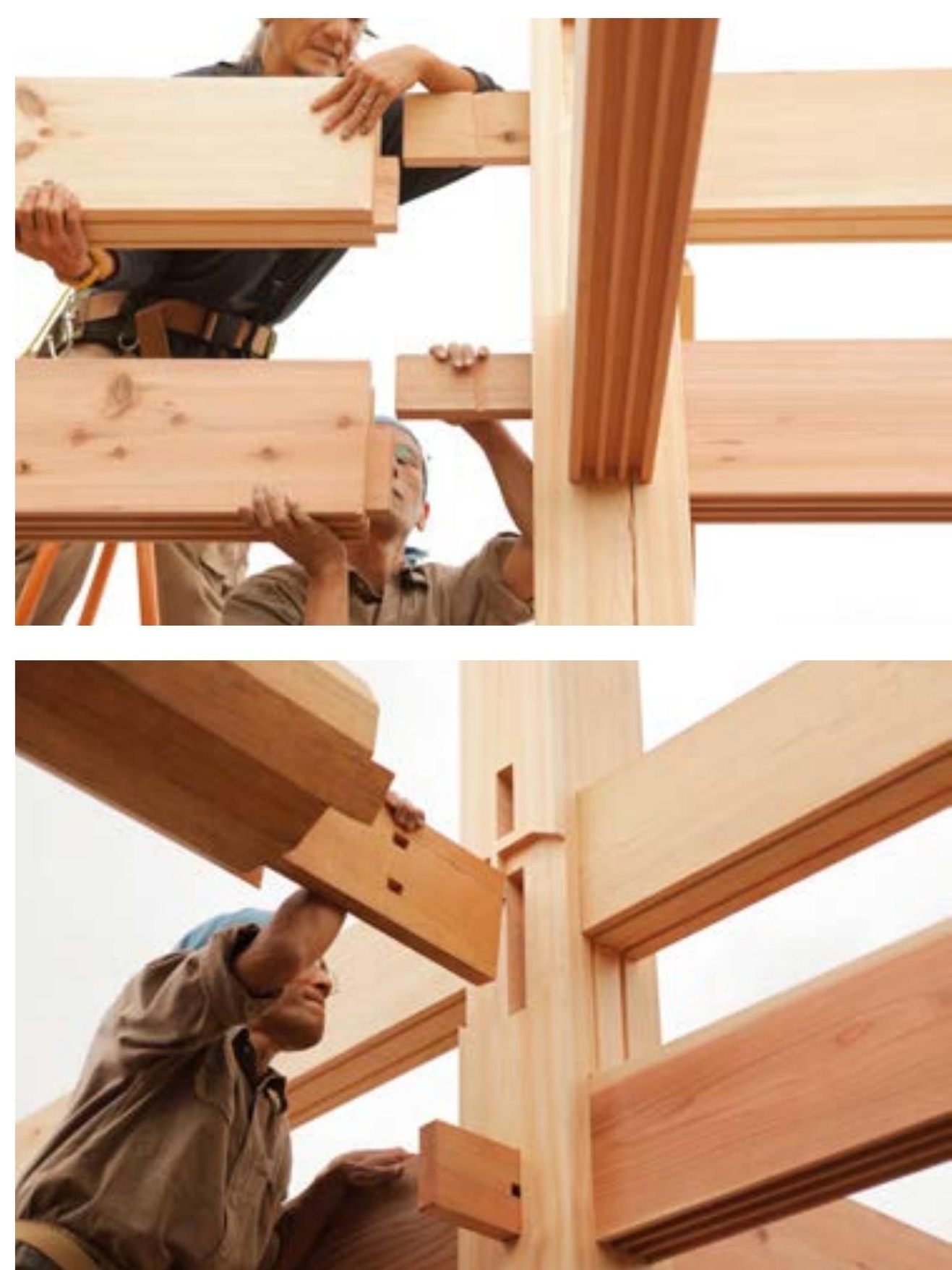


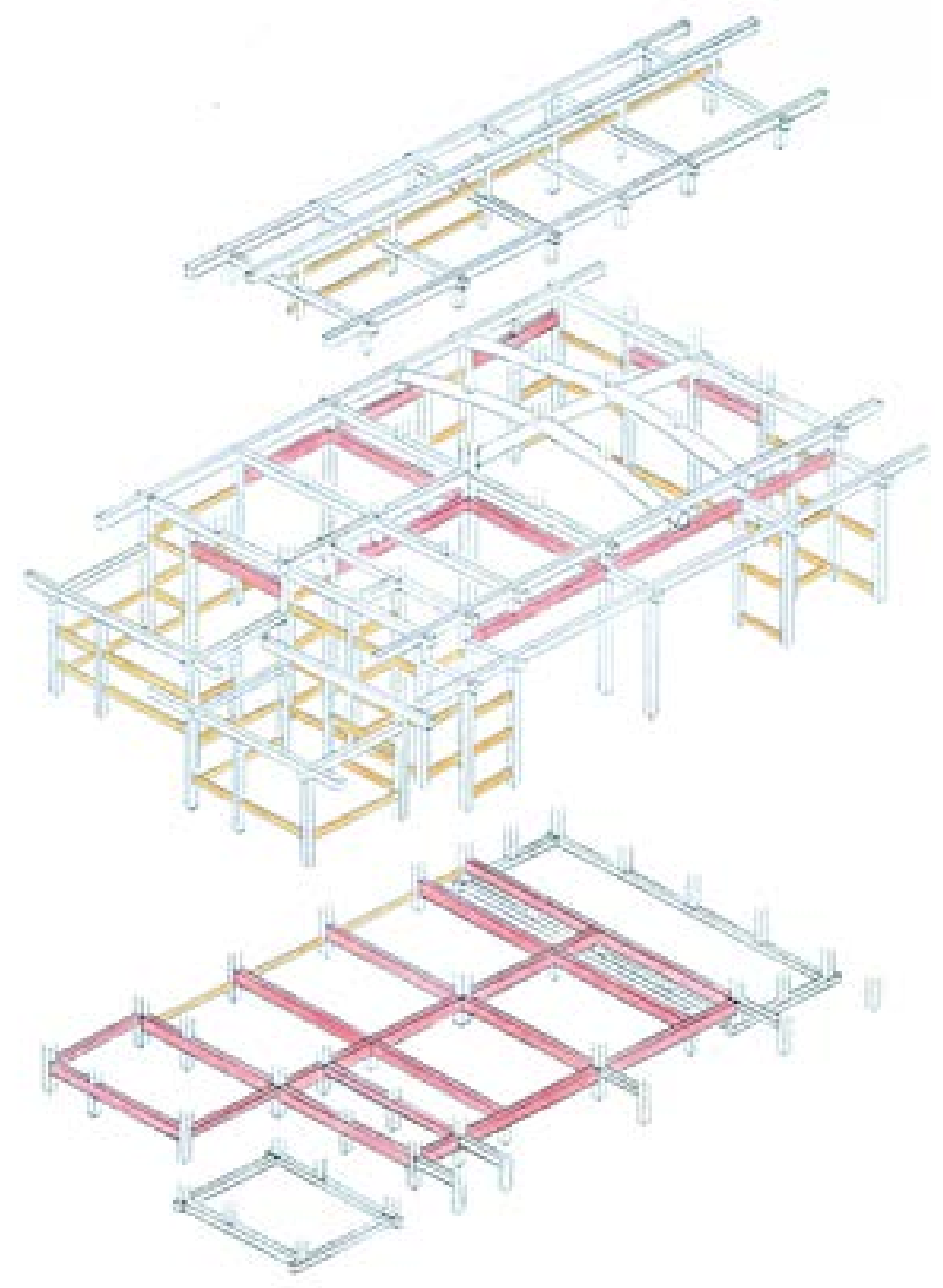

The various components of the jointed wooden frame, including the pillars, horizontal members, nuki, sashigamoi, and ashigatame, are intricately interlaced with joints. The result forms a whole that stands up to external loads with a kind of flexible resilience, not unlike the way an organism inhabits its environment. The wooden structure rests on cornerstones, but the two are structurally separate - the absence of a bond between the frame and the stones is a key feature of the traditional style.

Figure 1 shows a plan view the Kamogawa House's wooden structure (the nuki are in orange and the sashigamoi and ashigatame in red).
Los diversos componentes del armazón de madera ensamblada, incluidos los pilares, los elementos horizontales, nuki, sashigamoi, y ashigatame, están estrechamente entrelazados mediante juntas. El resultado forma un conjunto que soporta las cargas externas con una especie de resiliencia flexible, no muy distinta de la forma en que un organismo habita en su entorno. La estructura de madera se apoya en piedras angulares, pero ambas son estructuralmente independientes: la ausencia de unión entre el armazón y las piedras es una característica fundamental del estilo tradicional.

La figura 1 muestra una vista en planta de la estructura de madera de la Casa Kamogawa (las nuki aparecen en naranja y los sashigamoi y ashigatame en rojo).
(Figure 1) Exploded view of the Kamogawa House's wooden structure as designed | (Figura 1) Vista despiezada de la estructura de madera de la Casa Kamogawa según fue diseñada | (Figura 1) Vista explodida da estrutura de madeira da Casa Kamogawa assim como foi desenhada

Os vários componentes da armação de madeira articulada, incluindo os pilares, membros horizontais, nuki, sashigamoi, e ashigatame, são intrincadamente entrelaçados com juntas. O resultado forma um todo que resiste às cargas externas com uma espécie de resiliência flexível, não muito diferente da forma como um organismo habita o seu ambiente. A estrutura de madeira assenta em pedras angulares, mas os dois elementos estão estruturalmente separados - a ausência de uma ligação entre a armação e as pedras é um elemento chave do estilo tradicional.

A figura 1 mostra a planta da estrutura de madeira da Casa Kamogawa (as nuki estão em laranja e os sashigamoi e ashigatame em vermelho). 


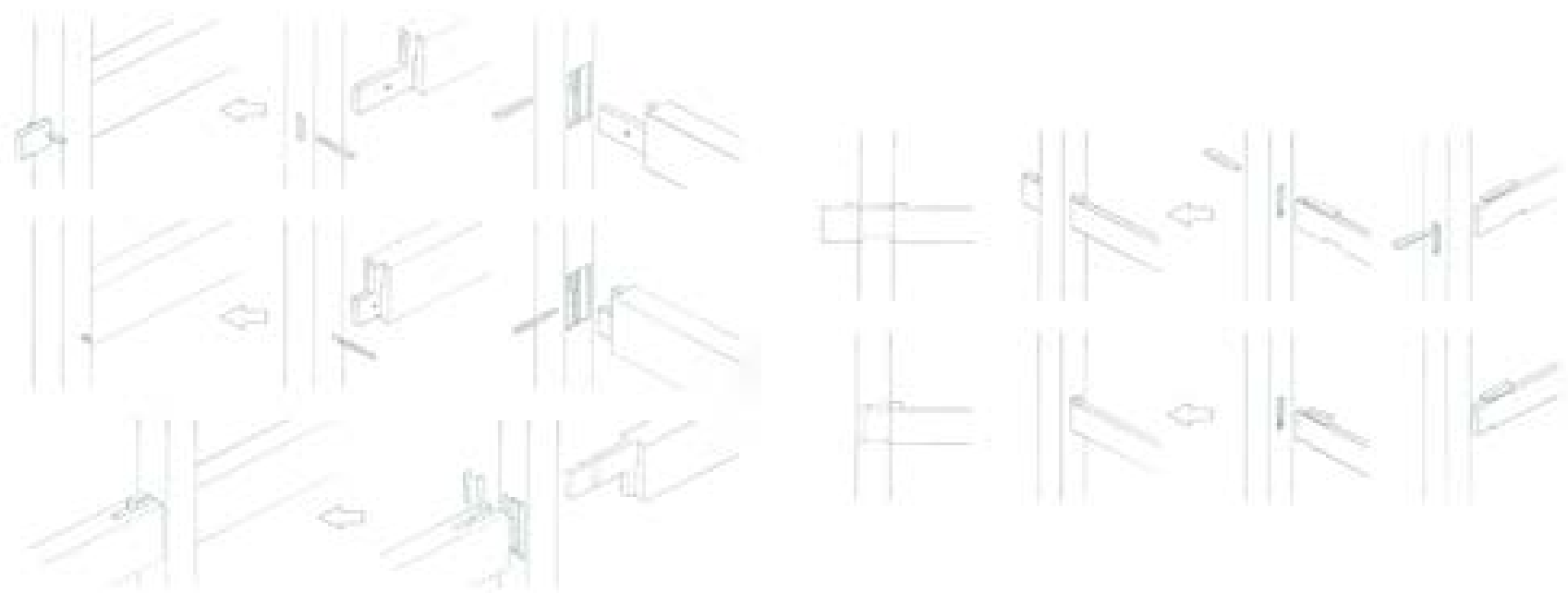

(Figure 2) Shikuchi joints used for sashigamoi, ashigatame, etc. Konehozohanasenjime/Oire, Konehozo-komisenjime/Oire, Konehozo-shachisenjime/ Oire | (Figura 2) Juntas Shikuchi utilizadas para sashigamoi, ashigatame, etc. Konehozo-hanasenjime/Oire, Konehozo-komisenjime/Oire, Konehozoshachisenjime/Oire | (Figura 2) Juntas Shikuchi usadas nos sashigamoi, ashigatame, etc. Konehozo-hanasenjime/Oire, Konehozo-komisenjime/Oire, Konehozo-shachisenjime/Oire
Todos los elementos estructurales tienen su función a la hora de conectar los pilares entre sí: las nuki proporcionan un armazón principalmente para los muros, los sashigamoi atraviesan los vanos y los ashigatame forman tirantes bajo los suelos. Y más allá de su función estructural, las nuki, los sashigamoi y los ashigatame también refuerzan el edificio contra las cargas laterales que provocan los terremotos y tifones.

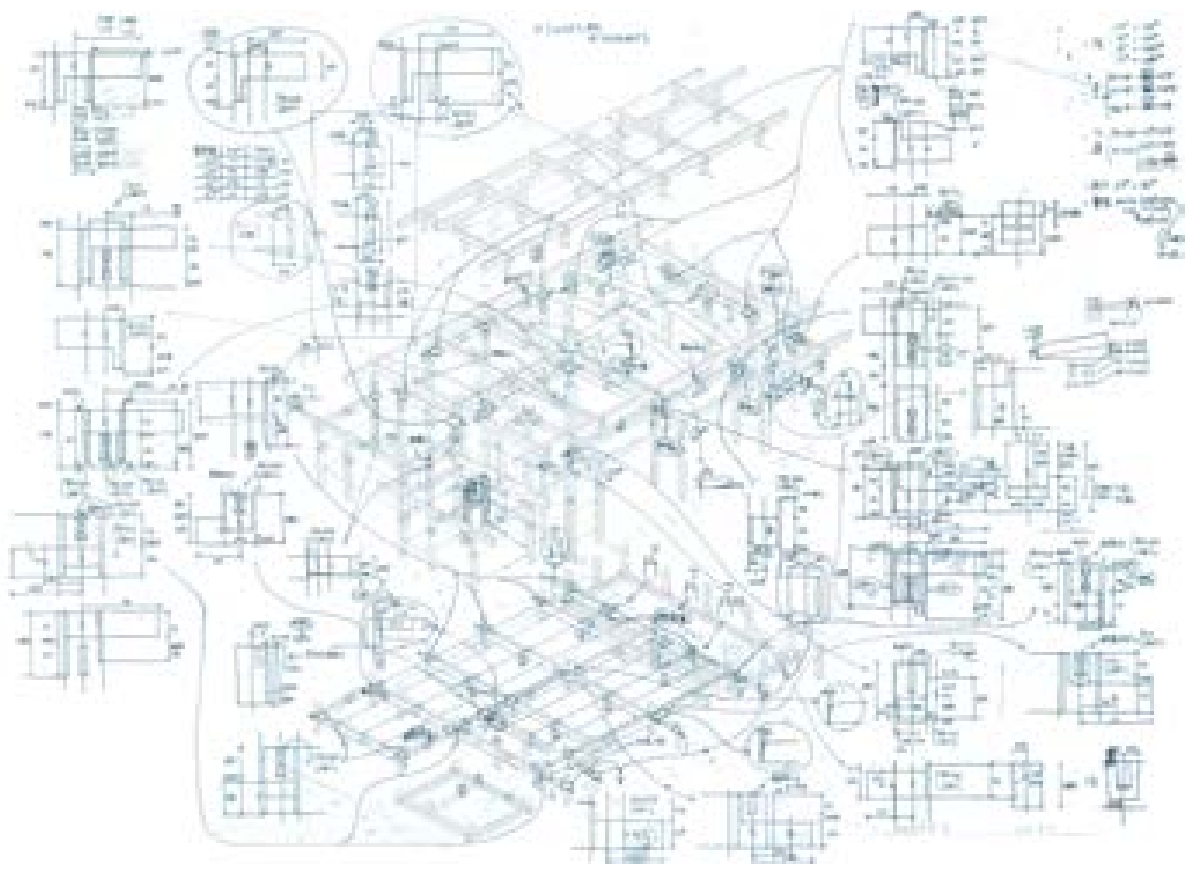

Todos os componentes da estrutura desempenham um papel na ligação dos pilares: as nuki fornecem uma estrutura sobretudo para as paredes; os vãos dos sashigamoi e os ashigatame formam tirantes sob os pisos. E para além do seu papel estrutural, as nuki, os sashigamoi e ashigatame também reforçam o edifício contra as cargas laterais resultantes de terramotos e furacões.

\footnotetext{
$<$ Exploded view of the Kamogawa House's wooden structure as built | Vista despiezada de la estructura de madera de la Casa Kamogawa tal como fue construida | Vista explodida da estrutura de madeira da Casa Kamogawa assim como foi construída

$>$ Erection of the framework of the Kamogawa House | Construcción del entramado de la Casa Kamogawa | Montagem da armação da Casa Kamogawa (Ken Kusakari)
} 


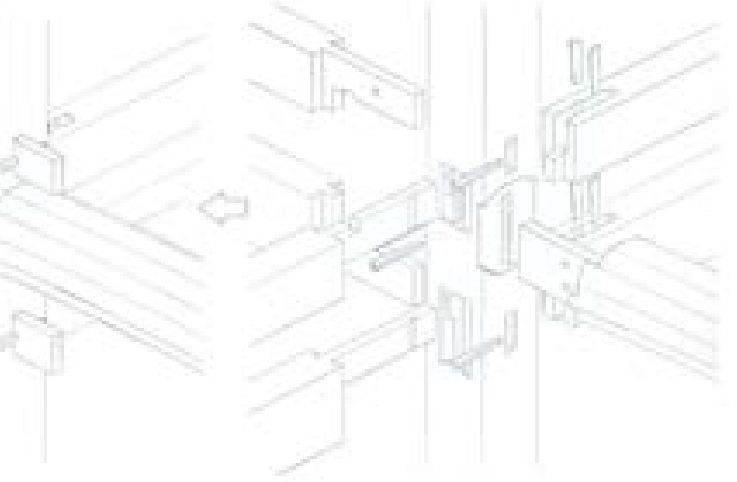

(Figure 4) Timber joinery at the central pillar of the Kamogawa House | (Figura 4) Carpintería de madera en el pilar central de la Casa Kamogawa | (Figura 4) Trabalho de carpintaria no pilar central da Casa Kamogawa

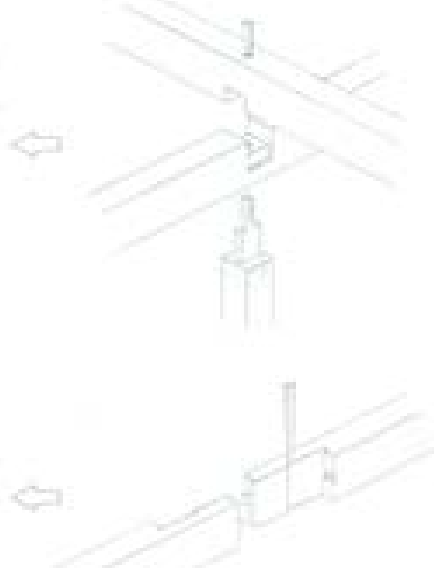

(Figure 5) Shikuchi and tsugite joints used for horizontal members and uprights. Aigaki-watariago/Jyuhozo-warikusabijime, Kanawatsugi| (Figura 5) Juntas Shikuchi y tsugite utilizadas para elementos horizontales y pies derechos. Aigaki-watariago/Jyuhozo-warikusabijime, Kanawatsugi | (Figura 5) Juntas Shikuchi e tsugite usadas nos membros horizontais e verticais. Aigaki-watariago/Jyuhozo-warikusabijime, Kanawatsugi
The separation between the wooden structure and the cornerstones is vital when a building is subject to significant lateral load, as the frame can move atop the stones - this detachment keeps the frame free of lateral stress from below and thereby spares the house itself from strain. Figs. 2-5 show a standard shikuchi and tsugite arrangement, a traditional Japanese timber building technique.
La separación entre la estructura de madera y las piedras angulares es vital cuando un edificio está sometido a una carga lateral importante, puesto que el armazón puede desplazarse sobre las piedras: con esta separación el armazón no sufre esfuerzos laterales desde abajo y, por consiguiente, evita deformaciones a la propia casa. Las figuras $2-5$ muestran una disposición típica de shikuchi y tsugite, una técnica constructiva con madera japonesa tradicional.
A separação entre a estrutura de madeira e as pedras angulares é crucial quando um edifício está sujeito a cargas laterais significativas, uma vez que a estrutura pode mover-se sobre as pedras - este desprendimento mantém a estrutura livre de tensões laterais inferiores, poupando assim a própria casa de tensão. As figuras 2-5 mostram uma disposição shikuchi e tsugite padrão, uma técnica tradicional Japonesa de construção em madeira.

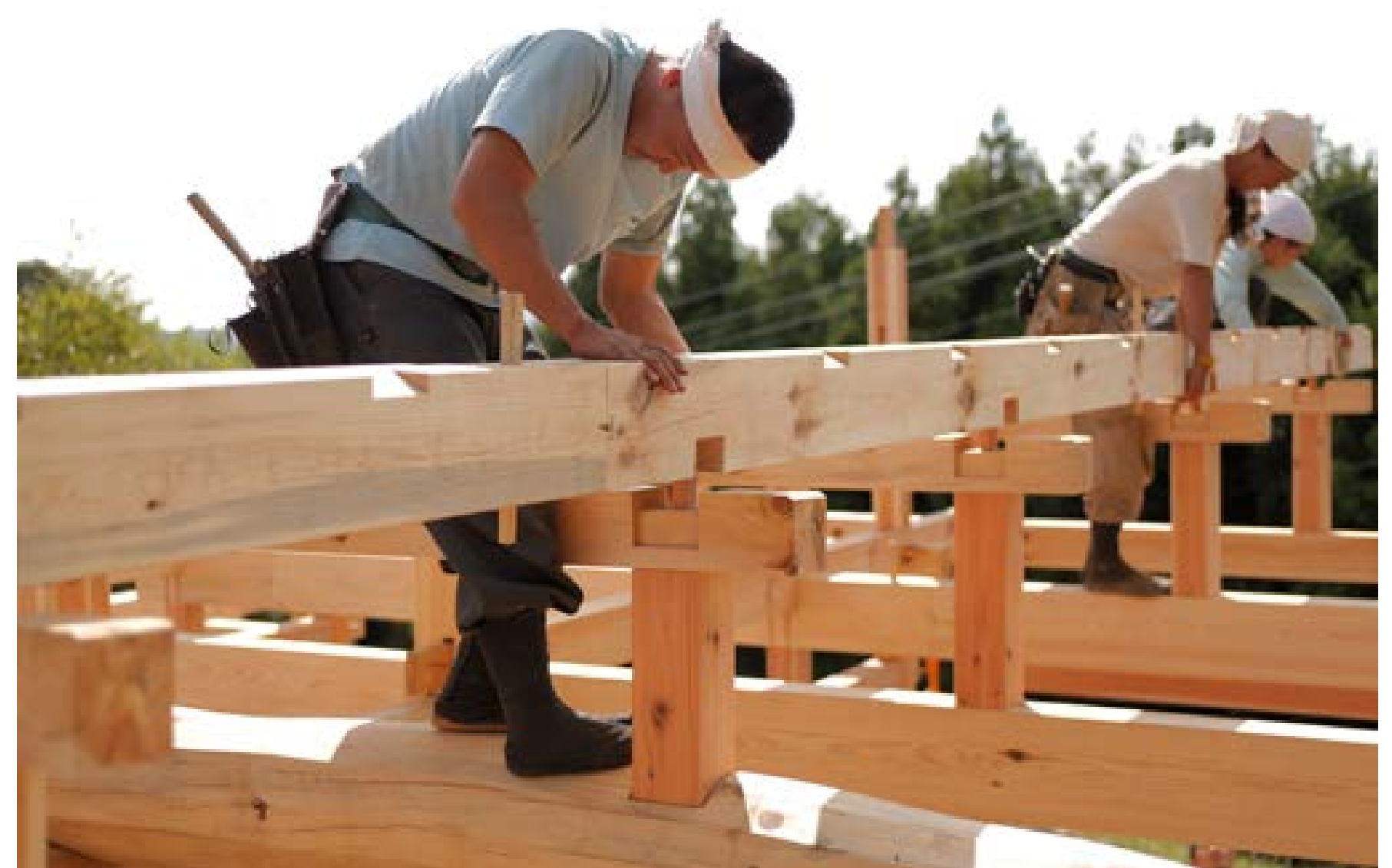


All the walls are tsuchikabe. The first coating of tsuchikabe, a thick layer of mud plaster, also has a major structural role. Made with a kneaded mixture of earth, rice straw, and water, fermented for more than six months, this plaster makes the walls more robust and reinforces the framework's overall bearing capacity.

After applying this plaster to the bamboo laths forming the house's walls, we let the wall dry out and then began the finishing process: multiple coats of an earth, straw-fiber, sand, and water mixture, using a different blend each time so as to vary the textures and create a subtle, good-looking finish. For the outer finish we used a mix of lime plaster and water to enhance the surface's water resistance.
Todos los muros son tsuchikabe. El primer revestimiento de tsuchikabe, una espesa capa de barro, también tiene una importante función estructural. Elaborado con una mezcla de tierra, paja de arroz y agua amasada, fermentada durante más de seis meses, este enlucido hace los muros más robustos y refuerza la capacidad de carga total del armazón.

Tras aplicar este enlucido a las tiras de caña bambú que forman los muros de la casa, se deja secar y entonces comienza el proceso de acabado: numerosas capas de una mezcla de tierra, fibra de paja, arena y agua cada vez en proporciones distintas para alternar las texturas y crear un acabado sutil y bonito. Para el acabado exterior utilizamos una mezcla de agua y mortero de cal para mejorar la resistencia al agua de la superficie.
Todas as paredes são de tsuchikabe. O primeiro revestimento de tsuchikabe, uma espessa camada de argamassa de barro, tem também um papel estrutural importante. Feita com uma mistura amassada de terra, palha de arroz e água, fermentada durante mais de seis meses, esta argamassa torna as paredes mais robustas e reforça a capacidade global de suporte da armação.

Depois de aplicar esta argamassa nas ripas de bambu que formam as paredes da casa, deixamos a parede secar e depois começamos o processo de acabamento: múltiplas camadas de uma mistura de terra, fibra de palha, areia e água, utilizando uma mistura diferente de cada vez, de forma a variar as texturas e criar um acabamento subtil e bonito. Para o acabamento exterior, utilizámos uma mistura de argamassa de cal e água para aumentar a resistência da superfície à água.

1: Construction of the tsuchikabe: lattice of bamboo laths at the Kamogawa House 2: Result of the first mud-coating process for tsuchikabe 3: Applying the second mud coating for tsuchikabe |1: Construcción del tsuchikabe: celosías de tiras de bambú en la Casa Kamogawa 2: Resultado del primer proceso de revestimiento de barro para tsuchikabe 3: Aplicación de la segunda capa de barro para tsuchikabe| 1: Construção da treliça tsuchikabe de ripas de bambu na Casa Kamogawa 2: Resultado do primeiro processo de revestimento de barro da tsuchikabe 3: Aplicação da segunda camada de barro na tsuchikabe
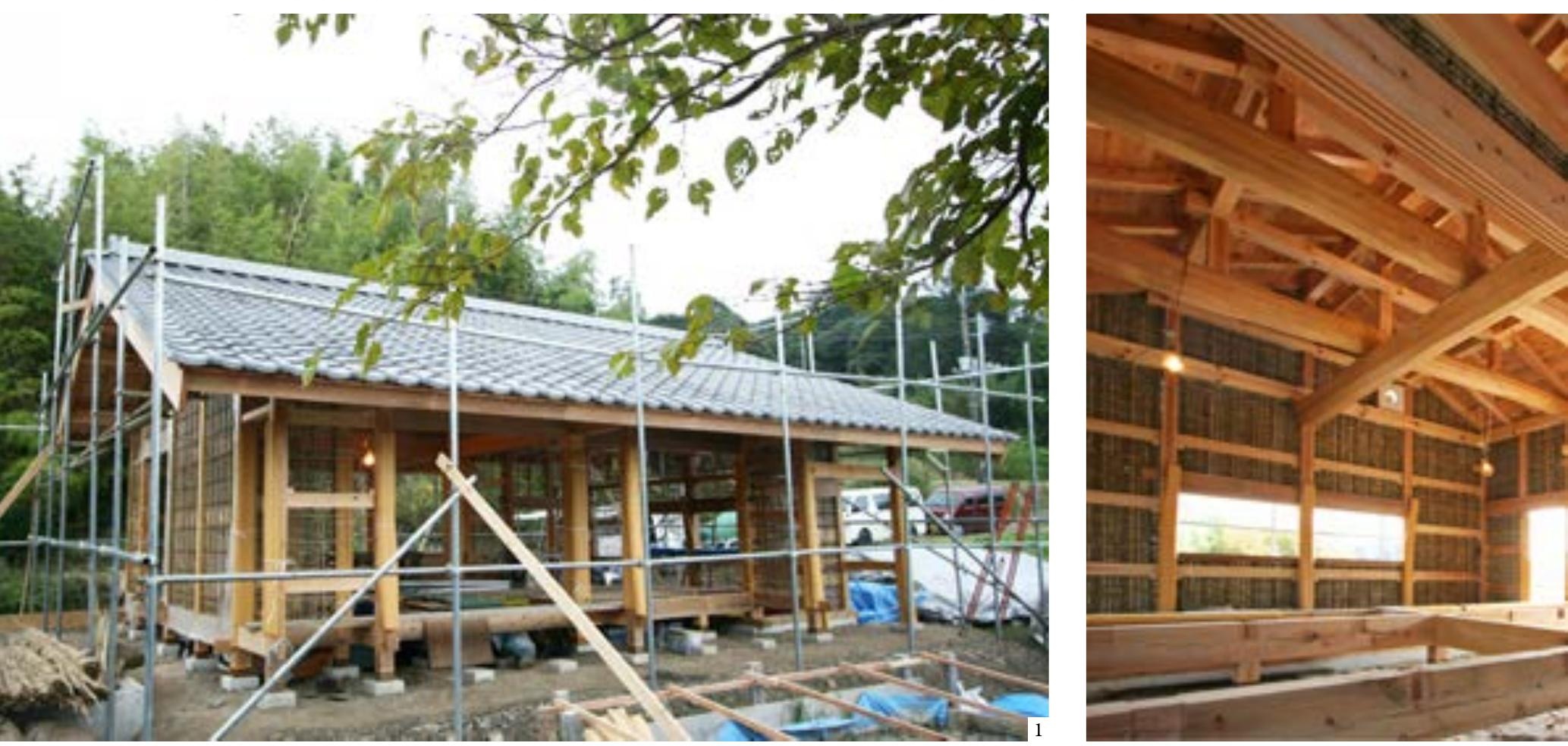
One of the defining features of traditional Japanese-style houses is that they reflect harmony and oneness with climate and their natural setting a conscious embrace of humanity with nature. Traditional approaches require readily available, easily accessible materials. All the wood, earth, bamboo, rice straw, and stone that Seyseysha used for the Kamogawa House was sourced in Japan.

As to allowing for climatic conditions, traditional methods feature a range of techniques for enhancing comfort during the hot, humid summers perhaps the chief consideration in our approach. All the various natural materials used in the structure, from the wood and tsuchikabe to the Japanese paper in the fittings, have properties that help keep interiors dry and comfortable in the muggy summer months and retain moisture in the dry chill of winter.
Una de las características que definen las casas de estilo japonés tradicional es que reflejan armonía y unidad con el clima y su entorno natural: una convivencia consciente del ser humano con la naturaleza. Los sistemas tradicionales requieren materiales fáciles de conseguir y asequibles. Toda la madera, tierra, bambú, paja de arroz y piedra que utilizó Seyseysha para la Casa Kamogawa procedía de Japón.

Para adaptarse a las condiciones climáticas, los métodos tradicionales cuentan con una serie de técnicas que mejoran la comodidad durante los veranos cálidos y húmedos, quizá la principal consideración de nuestro planteamiento. Todos los materiales naturales utilizados en la estructura, desde la madera y tsuchikabe hasta el papel japonés de las lámparas, tienen propiedades que ayudan a mantener los interiores secos y confortables en los bochornosos meses de verano y preservan de la humedad durante el invierno frío y seco.
Uma das características que definem as casas tradicionais Japonesas é que reflectem harmonia e unidade com o clima e o seu ambiente natural - um abraço consciente da humanidade à natureza.

As abordagens tradicionais requerem materiais facilmente disponíveis e de fácil acesso. Toda a madeira, terra, bambu, palha de arroz, e pedra que a Seyseysha utilizou para a Casa Kamogawa foi obtida no Japão.

Quanto à climatização, os métodos tradicionais apresentam uma gama de técnicas para aumentar o conforto durante os verões quentes e húmidos - talvez o principal aspecto considerado na nossa abordagem. Os diversos materiais naturais utilizados na estrutura, desde a madeira e o tsuchikabe até ao papel Japonês, têm propriedades que ajudam a manter os interiores secos e confortáveis nos meses abafados de Verão e a reter a humidade no frio seco do Inverno.
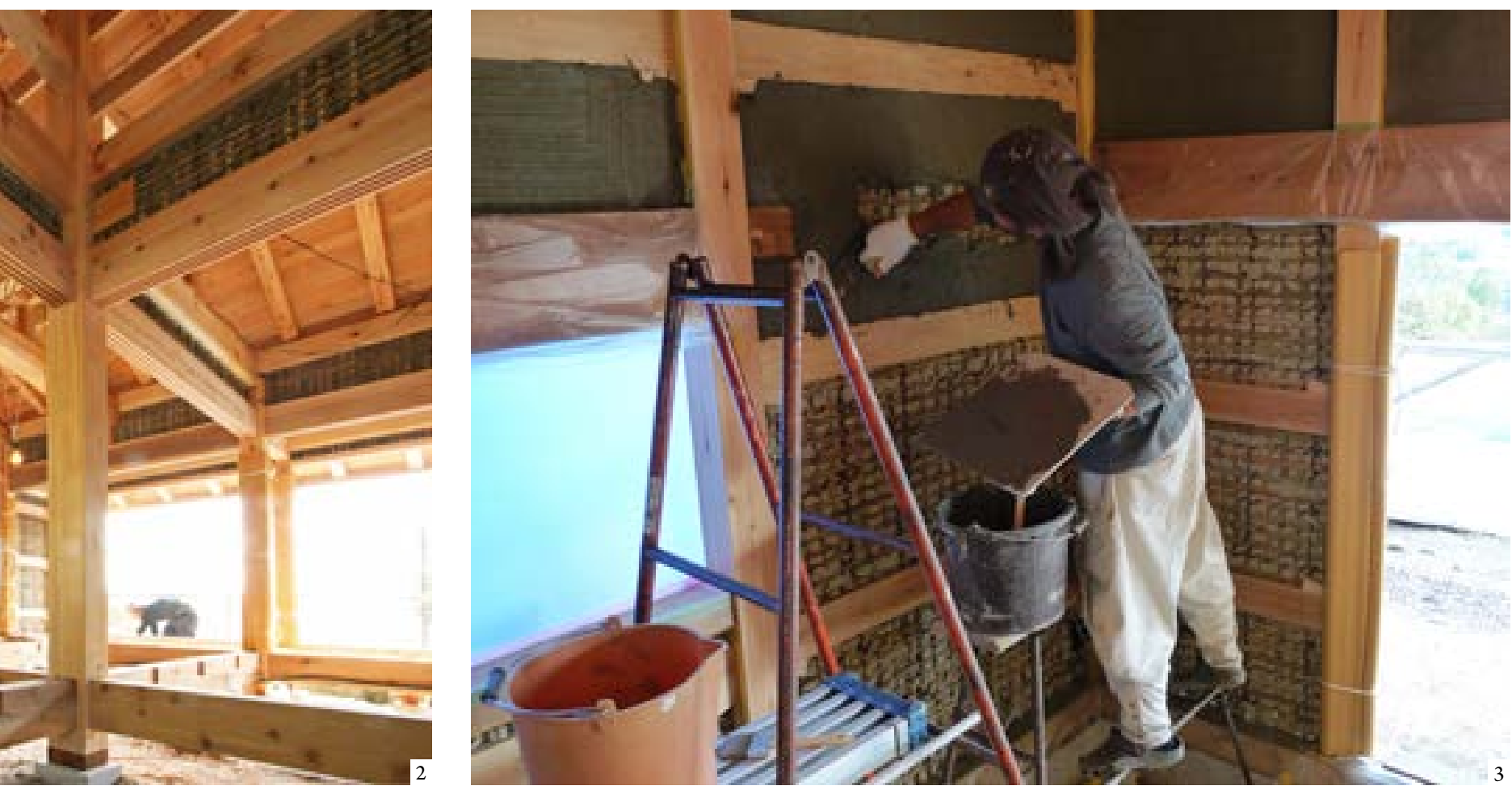
These traditional techniques also enhance air circulation, another vital factor in overall comfort. By employing thick, sturdy sashigamoi over wall openings to bolster the structure against lateral loads, we can reduce the number and span of load-bearing walls. Less partitioning means more spatial breadth, helping air circulate from the larger wall openings and making the interiors cool havens from the summer heat.

By leaving a larger gap between the floor and the ground (with a higher floor), the design favours underfloor airflow, keeping the wood of the substructure dry through greater air exposure and thereby extending the house's lifespan.
Estas técnicas tradicionales también mejoran la circulación del aire, otro factor decisivo para el confort general. Al utilizar sashigamoi gruesos y resistentes en todos los vanos de los muros para reforzar la estructura contra las cargas laterales, podemos reducir el número y la longitud de los muros portantes. Menos divisiones significa más amplitud espacial, lo que ayuda a que el aire circule desde las aberturas más grandes en los muros y a convertir a los interiores en frescos refugios durante el tórrido verano.

Al dejar un hueco mayor entre la planta y el terreno (elevando el suelo), el diseño favorece el flujo de aire por debajo de este, lo que mantiene seca la madera de la subestructura gracias a la mayor exposición al aire y, por consiguiente, amplía la vida útil de la casa.
Estas técnicas tradicionais também melhoram a circulação do ar, outro factor essencial em termos de conforto geral. Ao utilizar sashigamoi espessos e robustos sobre as aberturas das paredes para reforçar a estrutura contra as cargas laterais, podemos reduzir o número e os vãos das paredes de carga. Menos divisórias significa uma maior amplitude espacial, ajudando o ar a circular a partir das maiores aberturas nas paredes e transformando os interiores em abrigos frescos face ao calor do Verão.

Ao deixar um espaço maior entre o piso e o terreno (com um piso mais alto), este design favorece o fluxo de ar sob o pavimento, mantendo a madeira da subestrutura seca devido a uma maior exposição ao ar, prolongando assim a vida útil da casa.
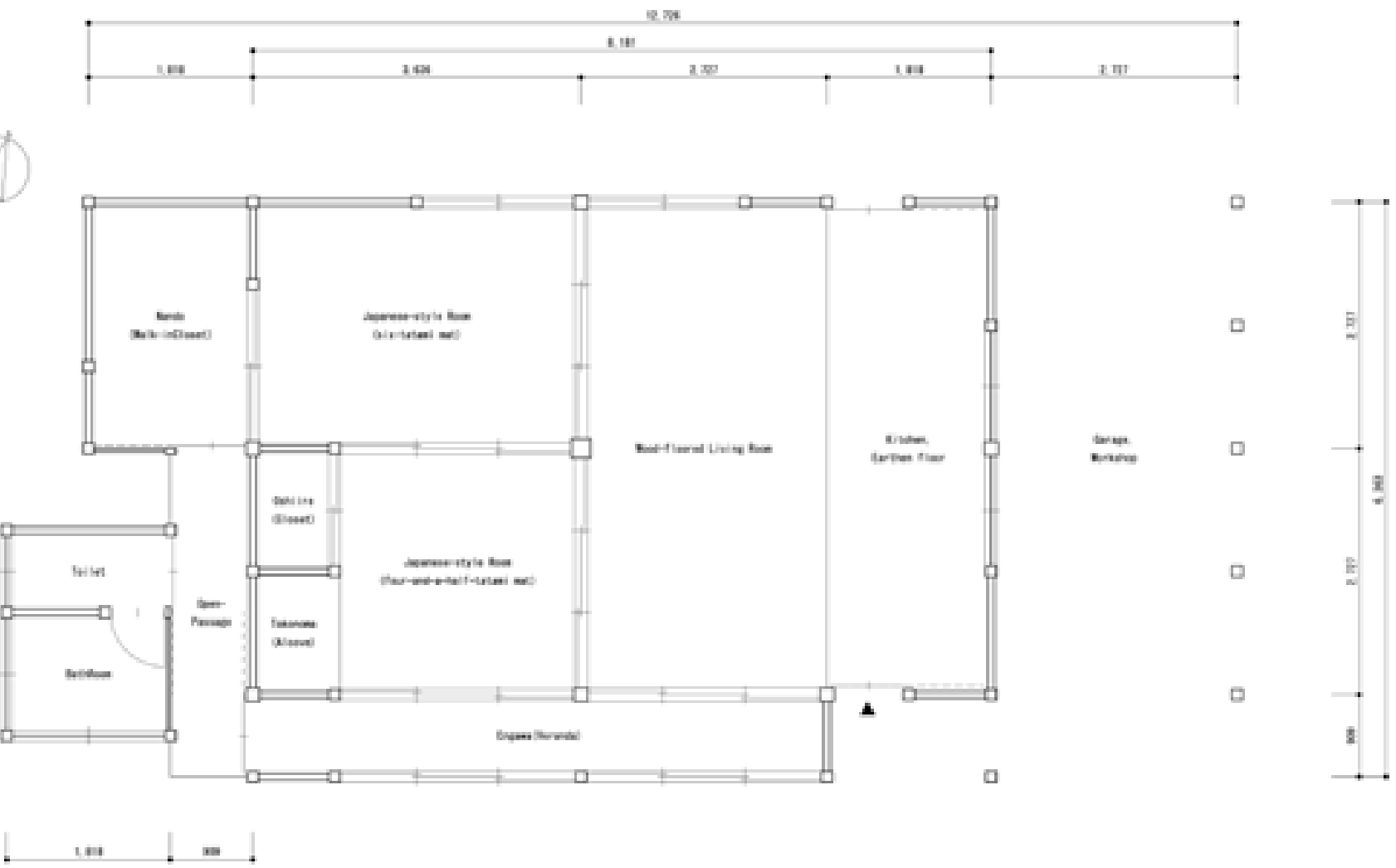

Floor plan of the Kamogawa House | Planta de la Casa Kamogawa | Planta da Casa Kamogawa 
Long eaves give shelter from rain, but their benefits go beyond shielding the dwelling from the elements, as eaves also help control indoor temperature. When the sun is high in the sky in summer, they cast cool shade; when it is low in winter, they deflect its slanting rays into the house, giving warmth.

For the layout of the Kamogawa House we made a compact adaptation of the floor plans common in traditional Japanese farmhouses. At the entrance is an earthen floor, extending into a kitchen on the same level. One step above that is a wooden-floored living room - a place for the family to enjoy time together. Slightly higher are two tatami rooms, and an engawa (veranda) stretches along the south side.
Los largos aleros protegen de la lluvia, pero sus ventajas van más allá de resguardar a la vivienda de los elementos, ya que ayudan a controlar la temperatura interior. Cuando el sol está alto en verano proyectan una sombra refrescante y cuando está bajo en invierno desvían los rayos inclinados hacia el interior de la casa, calentándola.

Para el diseño de la Casa Kamogawa condensamos las plantas típicas de las casas de campo japonesas tradicionales. En la entrada hay un suelo de tierra que llega hasta la cocina, que está en el mismo nivel. Un escalón por encima está el salón con suelo de madera, un lugar para que la familia disfrute de los momentos que pasan juntos. Un poco más arriba hay dos habitaciones de tatami y un engawa (porche) ocupa toda la fachada sur.
Os beirais longos abrigam da chuva, mas os seus benefícios vão além de proteger a habitação das intempéries, já que os beirais também ajudam a controlar a temperatura interior. Quando o sol está alto no Verão, eles lançam uma sombra fresca; quando está baixo no Inverno, desviam os seus raios oblíquos para dentro da casa, dando calor.

Para o traçado da Casa Kamogawa fizemos uma adaptação compacta das plantas baixas que são comuns nas fazendas tradicionais Japonesas. À entrada encontra-se um chão de terra, que se estende até à cozinha no mesmo nível. Um degrau acima encontra-se uma sala de estar com chão de madeira - um lugar para a família desfrutar de tempo em conjunto. Um pouco mais acima encontram-se duas salas com tatami, e uma engawa (varanda) que se estende ao longo do lado sul.

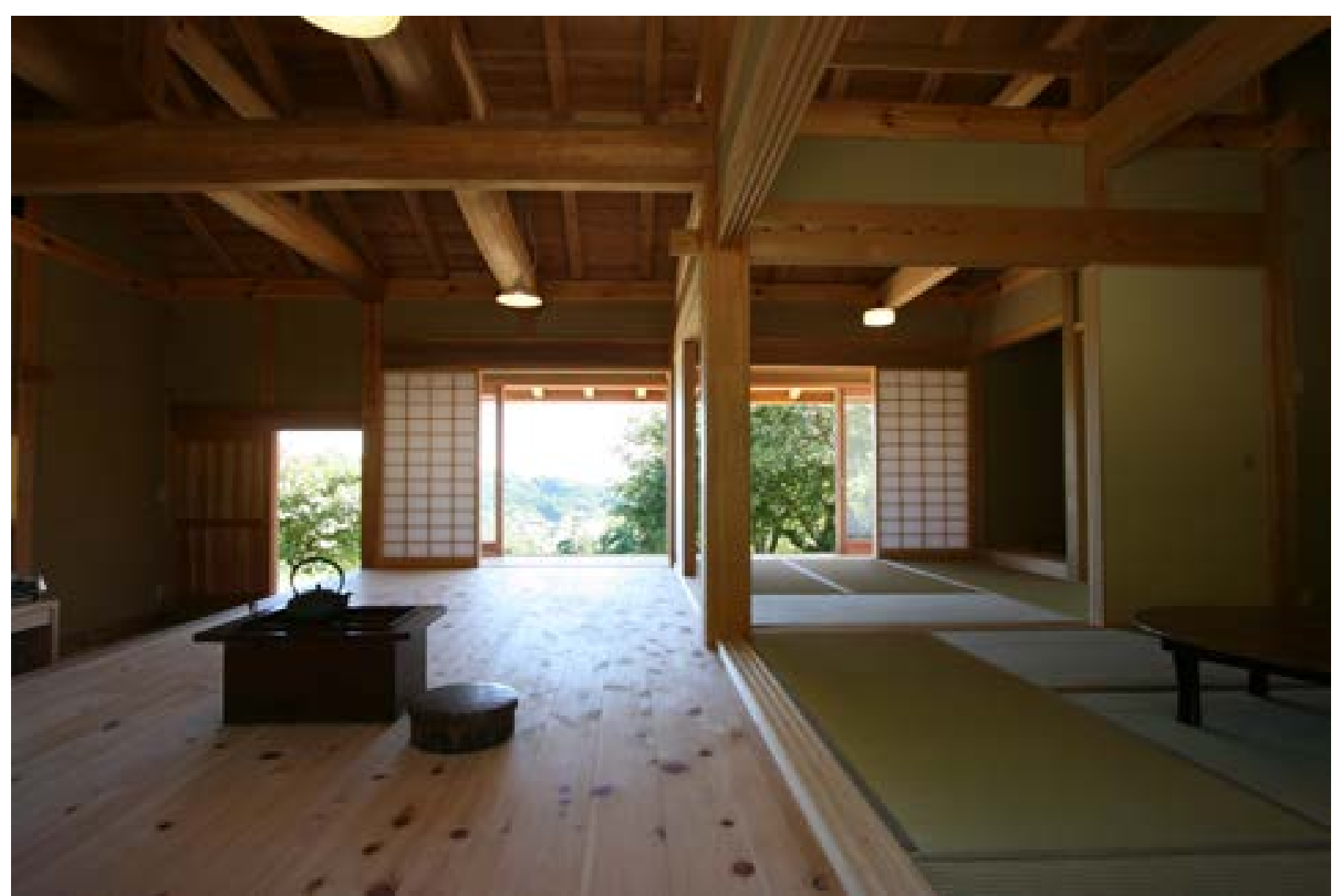

Interior of the Kamogawa House | Interior de la Casa Kamogawa | Interior da Casa Kamogawa 


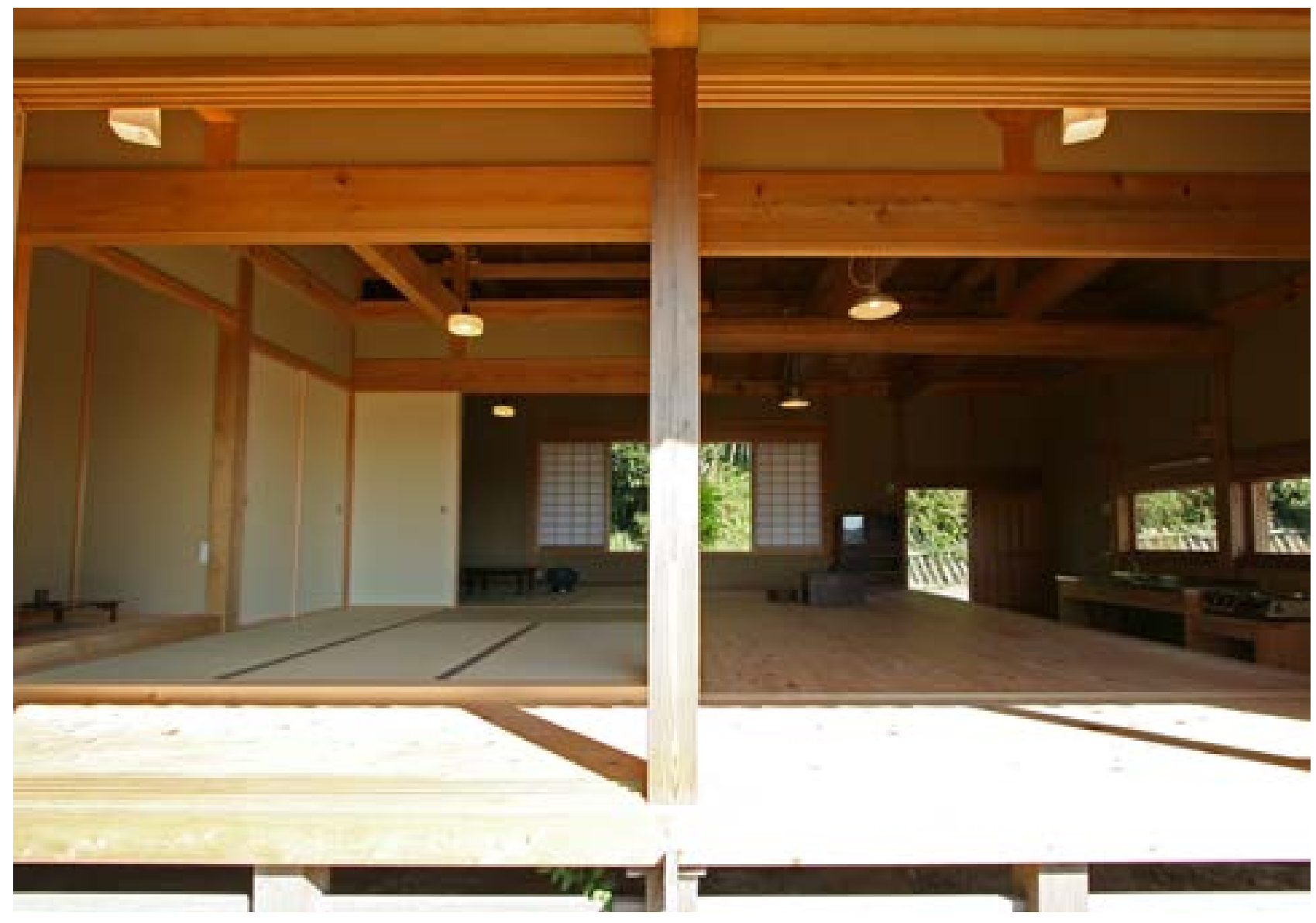

Interior of the Kamogawa House | Interior de la Casa Kamogawa | Interior da Casa Kamogawa

Both the wooden flooring and the Japanese-style flooring are designed to be sat on; no chairs are needed. The rooms can serve as drawing room, chanoma (Japanese living room), children's room or bedroom. Versatility is the defining quality of traditional Japanese rooms - and that inherent variety, with a single room having diverse functions, is a product of sparse interior design. The rooms of a traditional Japanese dwelling are almost free of furniture, with a characteristic minimal aesthetic. The floors of the Japanese-style rooms are covered with tatami mats. Of bundled straw wrapped in woven rush, 60 mm thick, tatami offers firm, supple cushioning, ideal for Japan's floororiented domestic life.

The tokonoma (alcove) is slightly above floor level, highlighting its unique role as a shady space, a threshold between this realm and the spirit world. Often
Tanto el suelo de madera como el de estilo japonés están pensados para sentarse sobre ellos, por lo que no hacen falta sillas. Las habitaciones pueden servir de sala de estar, chanoma (salón japonés), cuarto de niños o dormitorio. La versatilidad es la cualidad que define a las habitaciones japonesas tradicionales y esa variedad inherente en la que un solo espacio tiene diversas funciones es producto del parco diseño interior. Las estancias de una vivienda tradicional japonesa apenas tienen muebles y se caracterizan por su estética minimalista. Los suelos de las habitaciones de estilo japonés están cubiertos con esteras tatami. Realizado con manojos de paja recubiertos con juncos entrelazados y un grosor de 60 $\mathrm{mm}$, un tatami ofrece un acolchado firme y flexible, ideal para la vida doméstica japonesa, que se desarrolla en el suelo.

El tokonoma (nicho) está ligeramente elevado sobre el suelo para subrayar su función única como lugar apartado, un
Tanto o soalho de madeira como o soalho de estilo Japonês foram concebidos como assentos; não são necessárias cadeiras. Os quartos podem servir como sala de visitas, chanoma (sala de estar Japonesa), quarto das crianças ou quarto de dormir. A versatilidade é a qualidade que define os quartos tradicionais Japoneses - e essa variedade inerente, com um único quarto tendo funções diversas, é o resultado do design interior esparso. Os quartos de uma habitação tradicional Japonesa quase não têm mobiliário, e têm uma estética minimalista característica. Os soalhos das salas de estilo Japonês são cobertos com tapetes de tatami. Feitos de palha embrulhada num tecido de junco-solto, com $60 \mathrm{~mm}$ de espessura, o tatami oferece um amortecimento firme e flexível, ideal para a vida doméstica Japonesa, orientada para o chão.

A tokonoma (alcova) encontra-se ligeiramente acima do nível do chão, destacando o seu papel único como um espaço 
featuring calligraphy scrolls, craftwork, flower arrangements, and religious offerings, the tokonoma is a sacred recess that helps balance everyday actuality with a spiritual dimension and gives the dwelling a living heart.

Just as the tokonoma has deep significance, the engawa veranda is also more than a place of passage. In traditional Japanese-style homes, the engawa is a place to bask in the sun, chat with guests, put fruit and vegetables out to dry for preserves or do handicrafts. Most importantly, the engawa is the interface between indoors and outdoors, human domesticity and nature, one world and another, at once separating and uniting the two realms so that they can intermingle. When you sit on a tatami mat and gaze over the engawa, through the shady recesses under the eaves and out to the garden or countryside, the moment resonates with dynamic energy; the appeal of the scenery is stronger even than in the finest landscape painting. The engawa makes this magical interface possible. umbral entre el mundo material y el espiritual. En él se suelen exponer rollos de caligrafía, centros de flores y ofrendas religiosas. El tokonoma es un nicho sagrado que ayuda a mantener el equilibrio entre la rutina diaria y una dimensión espiritual y es el corazón del hogar.

Así como el tokonoma tiene un significado profundo, el porche engawa también es algo más que un lugar de paso. En las casas de estilo japonés tradicional, el engawa es un lugar para tomar el sol, charlar con los invitados, poner a secar frutas y verduras para hacer conservas o realizar manualidades. Ante todo, el engawa es la conexión entre interior y exterior, la vida doméstica y la naturaleza, este mundo y otro, y une y separa a la vez los dos ámbitos para que puedan entremezclarse. Cuando uno se sienta sobre una estera de tatami y dirige la mirada por encima del engawa, a través de las sombras de los aleros y hacia el jardín o el horizonte, el momento está lleno de energía dinámica y la escena es mucho más seductora que la de la mejor pintura de paisajes. El engawa hace posible esta conexión mágica. sombroso, um limiar entre este reino e o mundo dos espíritos. Contendo frequentemente pergaminhos caligráficos, artesanato, arranjos florais e oferendas religiosas, a tokonoma é um recanto sagrado que ajuda a equilibrar a actualidade quotidiana com uma dimensão espiritual, e dá à habitação um coração vivo.

Tal como a tokonoma tem um significado profundo, a varanda engawa é mais do que um local de passagem. Nas casas tradicionais de estilo Japonês, a engawa é um lugar para tomar banhos de sol, conversar com os hóspedes, colocar fruta e legumes a secar para fazer conservas, ou fazer artesanato. Mais importante ainda, a engawa estabelece a ligação entre o interior e o exterior, a domesticidade humana e a natureza, um mundo e outro, separando e unindo simultaneamente os dois reinos para que se possam misturar. Quando nos sentamos num tapete de tatami e olhamos para as engawa, através dos recantos sombrosos debaixo dos beirais, na direcção do jardim ou do campo, o momento ressoa com energia dinâmica; o apelo do cenário é mais forte do que o da melhor pintura paisagística. A engawa torna possível esta ligação mágica.
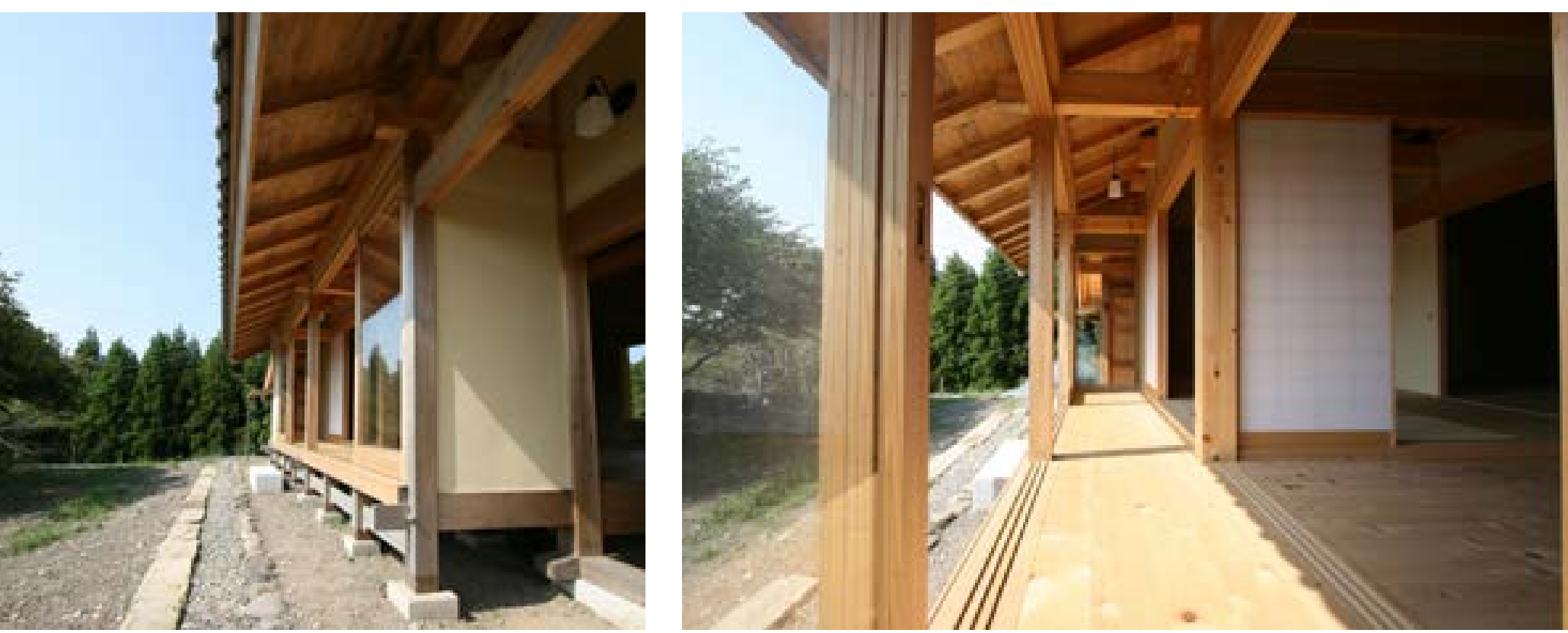

1: Amaochi (gravel strip onto which rain drops from the eaves) and engawa (veranda) 2: Engawa (veranda) | 1: Amaochi (franja de grava en la que cae la lluvia desde los aleros) y engawa (porche) 2 : Engawa (porche) | 1: Amaochi (faixa de gravilha onde cai a chuva dos beirais) e engawa (varanda) 2: Engawa (varanda) 
As one of the defining features of a traditional Japanese dwelling, thresholds add a touch of depth to the tokonoma, engawa, and many other elements. The fusuma (sliding doors) and shoji (sliding screens) in the Kamogawa House also have this borderline quality. Fusuma are thin, interlocking lattices of wood between multiple layers of Japanese paper on either side, while shoji have similar latticework but just one sheet of Japanese paper on one side. Both slide along grooved tracks and are removable; just pull a fusuma or shoji out of its grooves and you can turn what were separate rooms into a larger space. Fusuma mark spatial divisions whereas shoji filter light for softer, subtler partitioning.

Tokonoma, engawa, fusuma, and shoji all mark boundaries - but rather than simply demarcating spaces, they also join the worlds on either side. In that ambivalence lies their power to foster a unique connection, transcending spaces and worlds.
Como una de las características que definen a la vivienda japonesa tradicional, los umbrales añaden un toque de profundidad al tokonoma, el engawa y muchos otros elementos. Las fusuma (puertas correderas) y las shoji (mamparas correderas) de la Casa Kamogawa también tienen esta cualidad de línea divisoria. Las fusuma son finas celosías de madera dispuestas entre varias capas de papel japonés por ambas caras, mientras que las shoji tienen una celosía parecida pero solo están cubiertas con papel japonés en un lado. Ambas se deslizan por carriles ranurados y son desmontables; solo hay que sacar las fusuma o shoji del carril y las estancias separadas se convierten en un único espacio más amplio. Las fusuma marcan las divisiones espaciales, mientras que las shoji filtran la luz consiguiendo una separación más suave y sutil.

Tokonoma, engawa, fusuma, y shoji marcan límites, pero en lugar de tan solo demarcar espacios, también unen los mundos a ambos lados. En esa ambivalencia radica su capacidad para favorecer una conexión única que trasciende espacios y mundos.
Como uma das características definidoras de uma habitação tradicional Japonesa, os umbrais acrescentam um toque de profundidade à tokonoma, engawa, e muitos outros elementos. As fusuma (portas deslizantes) e os shoji (painéis deslizantes) na Casa Kamogawa têm também esta qualidade de fronteira. As fusuma são treliças finas cruzadas de madeira, com várias camadas de papel Japonês de cada lado, enquanto os shoji têm uma treliça semelhante, mas apenas uma folha de papel Japonês de um dos lados. Ambas deslizam ao longo de ranhuras e são removíveis; basta retirar uma fusuma ou um shoji das suas ranhuras e pode-se transformar o que eram salas separadas num espaço maior. As fusuma marcam divisões espaciais enquanto que os shoji filtram a luz para a criação de uma divisão mais suave e subtil.

As tokonoma, engawa, fusuma, e os shoji delimitam fronteiras - mas em vez de simplesmente demarcarem espaços, estes elementos também fazem parte dos mundos em ambos os lados. Nessa ambivalência reside o seu poder de fomentar uma ligação única, transcendendo espaços e mundos.

Exterior of the Kamogawa House | Exterior de la Casa Kamogawa | Exterior da Casa Kamogawa

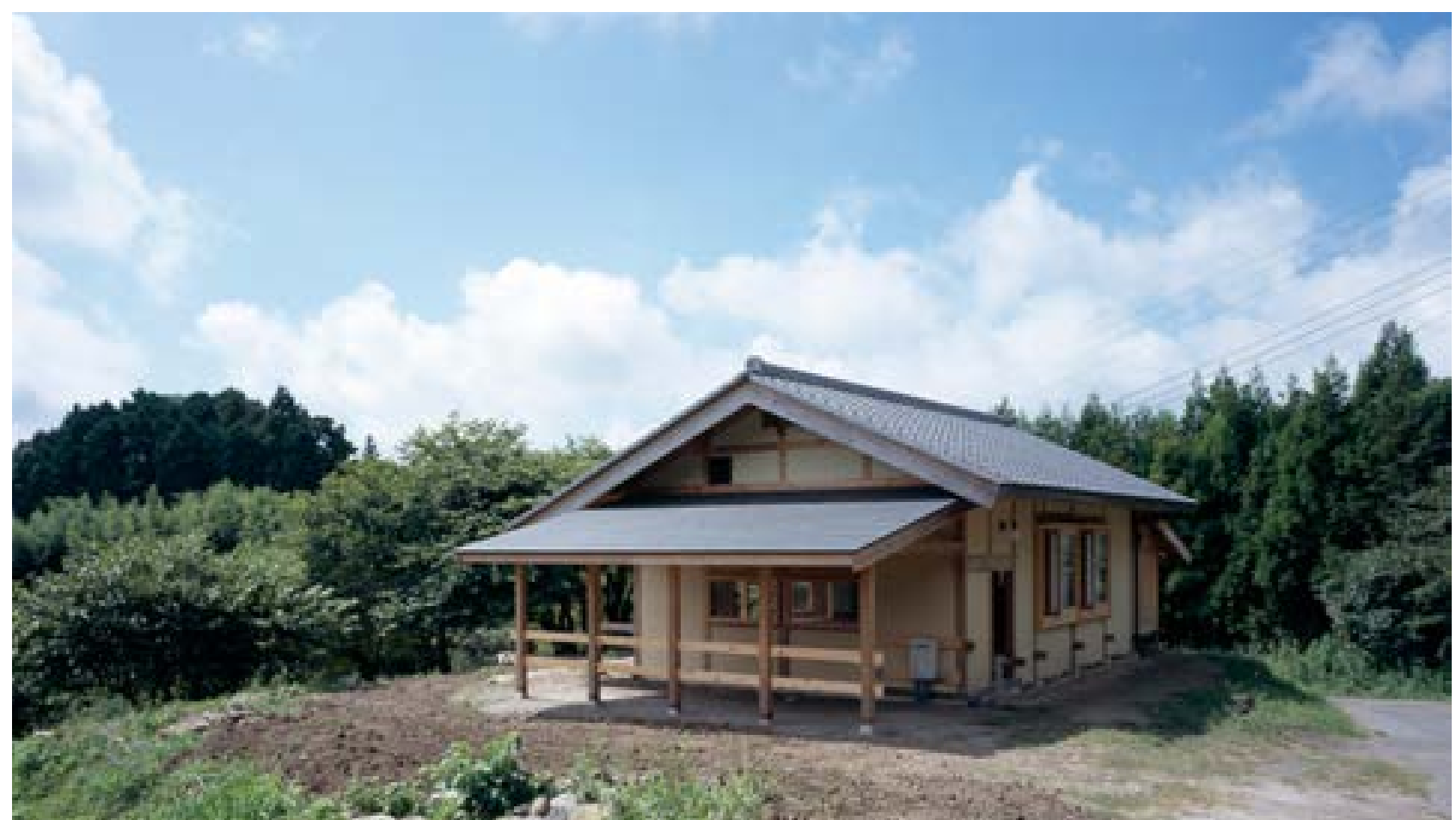




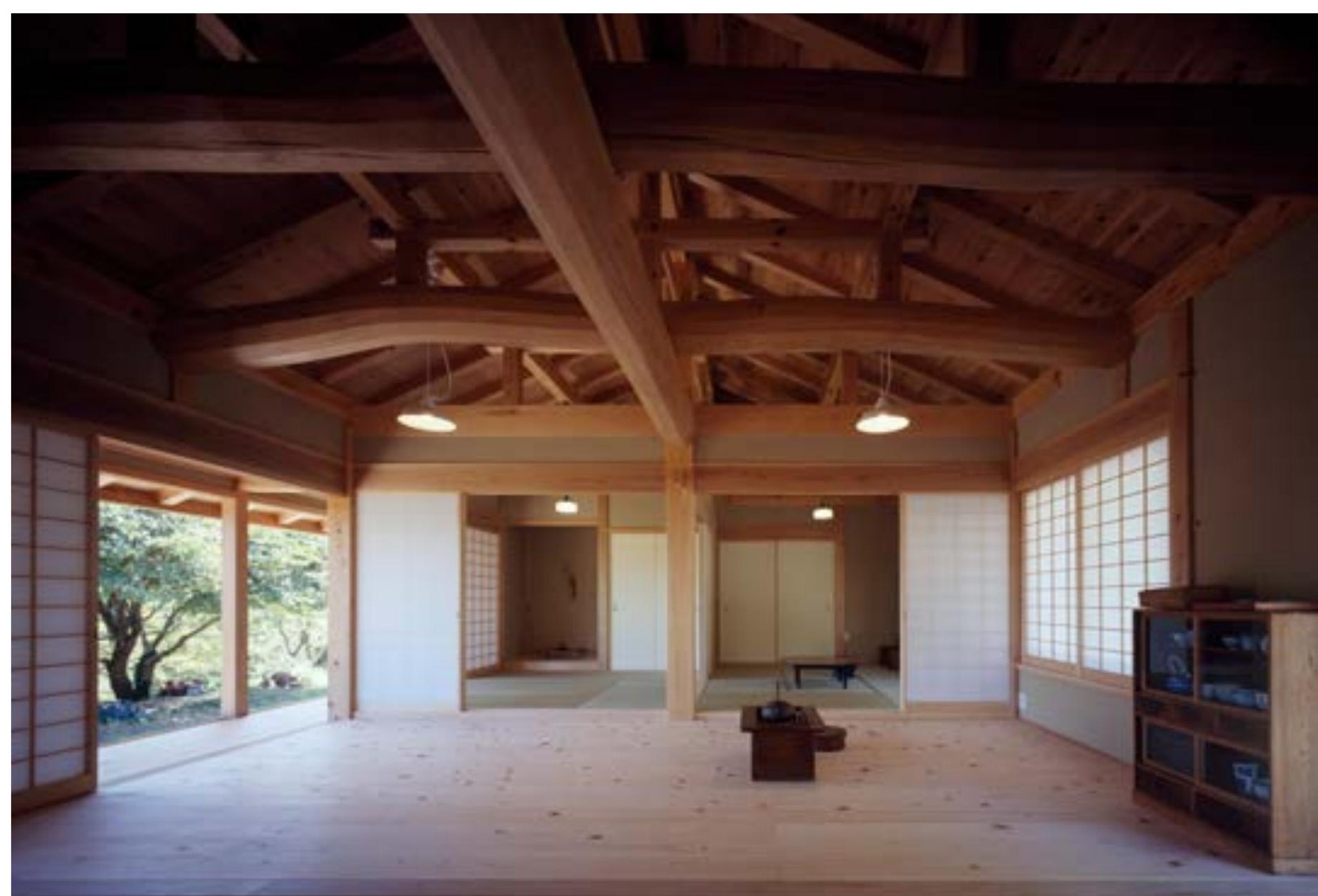

Interior of the Kamogawa House | Interior de la Casa Kamogawa | Interior da Casa Kamogawa (Masao Nishikawa, Jutaku-Kenchiku, 2011)

Echoing the way that traditional forms define houses in terms of structure, floor plan, and design, these forms also pervade Japanese culture as a whole. They are rooted in Japan's animistic, nature-focused worldview. For our forebears, cultivating natural forms was a means of subduing the self and freeing the mind from the ego - a yielding that allows us to commune with nature, with others and with the spirit world. Rather than binding us, these forms guide us into an inner realm where we are free to explore that world and experience its mysteries, undistracted by self.
Como reflejo de la manera en la que las formas tradicionales definen las casas en cuanto a su estructura, su planta y su diseño, estas formas impregnan la cultura japonesa en su conjunto. Están enraizadas en la cosmovisión de Japón, animista y centrada en la naturaleza. Para nuestros antepasados, cultivar las formas naturales era una manera de liberar la mente del ego y dominar el yo: un sometimiento que nos permite comulgar con la naturaleza, con los otros y con el mundo espiritual. En lugar de obligarnos por la fuerza, estas formas nos guían hacia una esfera íntima en la que somos libres de explorar y experimentar sus misterios sin que el yo nos distraiga.
Reiterando o modo como as formas tradicionais definem as casas em termos de estrutura, planta e design, estas formas também permeiam a cultura Japonesa como um todo. Têm as suas raízes na visão do mundo Japonesa, animista e centrada na natureza. Para os nossos antepassados, cultivar formas naturais era um meio de subjugar o eu e libertar a mente do ego - uma cedência que nos permite comungar com a natureza, com os outros e com o mundo espiritual. Em vez de nos limitar, estas formas guiam-nos para um reino interior onde somos livres de explorar esse mundo e experimentar os seus mistérios, sem nos distrairmos com nós próprios. 
In a traditional house, structure and design are one and the same. The wood and tsuchikabe forming the house's structure also constitute its aesthetic, as is plain to see in the finishes. Whenever we design a house, we believe we must take what nature offers; instead of just using natural resources and manipulating them into forms of our own, we see nature as something to listen to and learn from. If we are open and receptive, we can sense what will suit trees and earth and stone. Natural materials are free to inhabit their spontaneous, intrinsic shapes, harmonizing easily in a composite whole.

Our forebears firmly believed that they were merely occupying the world within a natural order. Whatever they did - whether making things or simply going about day-to-day life - they did it with a sense of respect and awe for the natural world. And though that value system has over time lost its hold, a few of us still adhere to its time-honored spirit.

Seyseysha holds those beliefs dear. Seeing traditional Japanese houses not just as places to live in but also as ways of reconnecting with age-old insights about dwelling in harmony with the environment, we will continue to draw on the past to craft homes for the future.
En una casa tradicional, estructura y diseño son una misma cosa. La madera y el tsuchikabe que forman la estructura de la casa también constituyen su estética, como se puede comprobar fácilmente en los acabados. Siempre que diseñamos una casa creemos que debemos tomar lo que nos ofrece la naturaleza: en lugar de limitarnos a usar los recursos naturales y manipularlos a nuestro antojo, vemos la naturaleza como algo a lo que escuchar y de lo que aprender. Si estamos abiertos y somos receptivos, podemos sentir qué es lo que conviene a los árboles, la tierra y las piedras. Los materiales naturales tienen libertad para habitar sus formas intrínsecas y espontáneas y componen con facilidad un conjunto armonioso.

Nuestros antepasados creían firmemente que tan solo ocupaban el mundo dentro de un orden natural. Cualquier cosa que hicieran -ya fuera fabricar objetos o vivir el día a día- lo hacían con respeto y fascinación por el mundo natural. Y aunque ese sistema de valores haya perdido hace tiempo su ascendiente, algunos todavía permanecemos fieles a su espíritu de larga tradición.

Seyseysha da mucha importancia a estas creencias. Consideramos que las casas tradicionales japonesas no son simplemente lugares donde vivir, sino formas de reencontrarse con conocimientos seculares sobre la vida en armonía con el entorno, y seguiremos aprovechando las enseñanzas del pasado en la creación de hogares para el futuro.
Numa casa tradicional, a estrutura e o design são uma e a mesma coisa. A madeira e o tsuchikabe que formam a estrutura da casa também fazem parte da sua estética, como se pode ver nos acabamentos. Sempre que projectamos uma casa, acreditamos que devemos aproveitar o que a natureza nos oferece; em vez de apenas utilizarmos os recursos naturais e manipulá-los em formas ditadas por nós, vemos a natureza como algo a ouvir e com que aprender. Se formos abertos e receptivos, podemos sentir o que se adequa às árvores, à terra e à pedra. Os materiais naturais são livres de habitar as suas formas espontâneas e intrínsecas, harmonizando-se facilmente num todo composto.

Os nossos antepassados acreditavam firmemente que estavam meramente a ocupar o mundo dentro de uma ordem natural. Fizessem o que fizessem - quer construíssem coisas, ou simplesmente vivessem a sua vida quotidiana - faziam-no com um sentido de respeito e de admiração pelo mundo natural. E embora esse sistema de valores tenha perdido a sua força ao longo do tempo, alguns de nós ainda aderimos ao seu espírito honrado pelo tempo.

A Seyseysha tem em grande estima essas crenças. Vendo as casas tradicionais Japonesas não só como lugares para viver, mas também como formas de restabelecermos a ligação com os conhecimentos antigos sobre como viver em harmonia com o ambiente, continuaremos a recorrer ao passado para criar casas para o futuro.

\section{References | Referencias | Referências}

Group of “Toryo-ni-manabu-ie”. 2003. Toryo-ni-manabu-ie Zukai Mokuzo-dento-koho kihon-to-jissen (The house of learning from the master builder. The Illustration of Traditional Wooden Construction Method Basics and Practice). Tokyo: Shokokusha Co., Ltd.

Fukaya, Motohiro; and Suzuki, Hiroko. 2001. Zukai Mokuzo-kenchiku Dento-giho-jiten (The Illustrated Dictionary of Traditional Wooden Building Techniques). Tokyo: Shokokusha Co., Ltd.

Aoki, Shigeru, et al. 1995. Kenchiku Daijiten (Encyclopedia of Architecture and Building). Tokyo: Shokokusha Co., Ltd. 


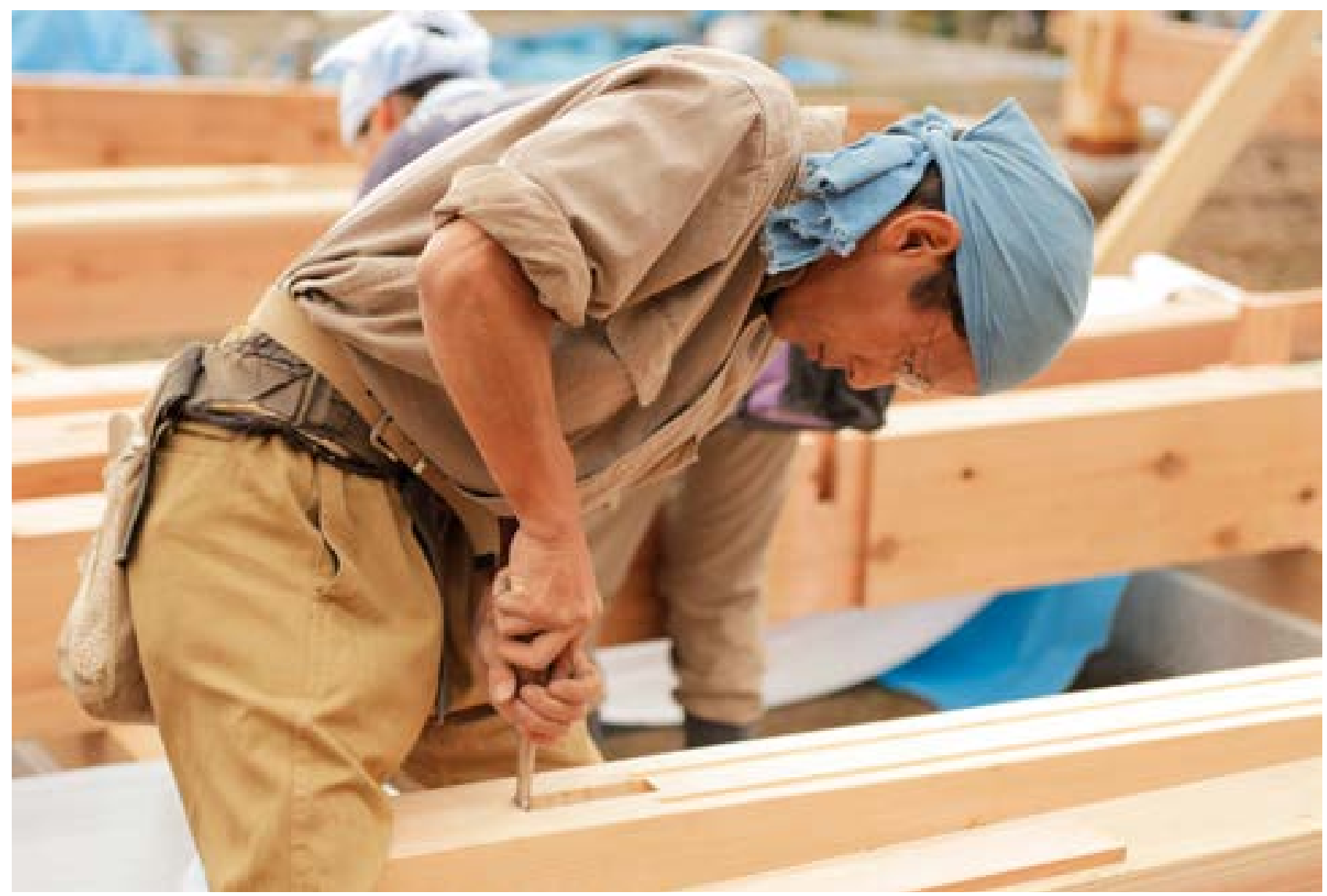

Makoto Fukada (Ken Kusakari)

Biography $\mid$ Biografía $\mid$ Biografia

\section{Makoto Fukada}

He is the master carpenter behind the firm Seyseysha, which uses traditional Japanese construction methods for a variety of building projects. Working with his apprentices, he fully oversees every project, from design and carpentry to on-site coordination, as a primary contractor. His experience in the field goes back to 1988 , when he was apprenticed to the master joiner and tea-utensil craftsman Kahei Yamada. Since founding his own company in 1997, he has continued to visit classical Japanese buildings across Japan and has studied traditional structures, floor plans and designs, building exquisite homes with these time-honored techniques.

Maestro carpintero y director de la empresa Seyseysha, que utiliza métodos tradicionales japoneses para diferentes proyectos de construcción. Trabaja con sus aprendices y supervisa en su totalidad cada proyecto - desde el diseño y la carpintería hasta la coordinación de la obra- como contratista principal. Su experiencia en este campo se remonta a 1988, cuando era aprendiz de Kahei Yamada, maestro carpintero y artesano de utensilios para el té. Desde que fundó su propia empresa en 1997 no ha dejado de visitar edificios clásicos por todo Japón y ha estudiado las estructuras, las plantas y los diseños tradicionales para construir hogares exquisitos con estas técnicas ancestrales.

Mestre carpinteiro por detrás da firma Seyseysha, que usa métodos de construção tradicional Japonesa para uma variedade de projectos de construção. No trabalho com os seus aprendizes, ele supervisiona inteiramente cada projecto, desde a concepção e carpintaria até à coordenação no local, como empreiteiro principal. A sua experiência na área remonta a 1988, quando foi aprendiz do mestre carpinteiro e artesão de utensílios de chá Kahei Yamada. Desde a fundação da sua própria empresa em 1997, continuou a visitar edifícios Japoneses clássicos por todo o Japão e estudou as estruturas tradicionais, plantas e desenhos, construindo casas requintadas com estas técnicas consagradas pelo tempo. 